\title{
Factors affecting the actual yield of active substances from anthocyanin-rich berries Faktory ovlivňující skutečný výtěžek aktivních látek z plodů bohatých na anthokyany
}

${ }^{1}$ Charles University in Prague, Faculty of Pharmacy, Department of Pharmacognosy, Hradec Kralove, Czech Republic ${ }^{2}$ Research and Breeding Institute of Pomology Holovousy Ltd., 50801 Horice, Czech Republic
Polášková A. ${ }^{1 凶}$, Spilková J. ${ }^{1}$, Matějičcek A. ${ }^{2}$, Studená H. ${ }^{1}$

${ }^{1}$ Katedra farmakognosie, Univerzita Karlova v Praze,

Farmaceutická fakulta v Hradci Králové, ČR

${ }^{2}$ Výzkumný a šlechtitelský ústav ovocnář́ský

Holovousy s. r. o., ČR

Received November 30, 2014, accepted January 30, 2015

Abstract The content of anthocyanins in fruits (Sambucus nigra. Vaccinium myrtillus. Aronia melanocarpa) and in some fruit (berry) products was determined by differential spectrophotometry, a method recommended by AOAC International (former Association of Official Analytical Chemists). The method takes advantage of the reversible pH-dependent transformation of the colour to the colourless form of anthocyanins. The procedure and evaluation were refined to allow measurements of incompletely specified anthocyanin mixtures. Parameters of the determination (buffer composition, $\mathrm{pH}$, stabilisation of samples, reference standards) were optimised. Using the modified method, anthocyanins in various matrices (fruits, syrups, wines) were measured with the aim to explain possible losses of these active substances during processing and/or storage of fruit products. Real samples of commercial products recommended conventionally as a valuable source of antioxidants were analysed and in some of them only low levels of anthocyanins were found. In a model arrangement, anthocyanins in the skin and the pulp of Sambucus nigra fruits were extracted separately. In all samples of various cultivars, anthocyanins were present predominantly in the skin (up to $90 \%$ of the total content). Considering this, among other factors, a suitable extraction technology might improve the quality of berry products substantially.

Slovak Obsah anthokyanů v plodech (Sambucus nigra. Vaccinium myrtillus. Aronia melanocarpa) a v některých produktech z plodů byl abstract stanoven diferenční spektrofotometrií, metodou doporučenou AOAC International (dřívější Associace oficiálních analytických chemiků). Metoda využívá reverzibilní transformace barevné formy anthokyanů na bezbarvou v závislosti na pH. Postup i způsob hodnocení byly upraveny tak, aby umožnily měření i u ne zcela přesně definovaných směsí anthokyanů. Byly optimalizovány podmínky stanovení (složení pufrů, pH, stabilizace vzorků, referenční standardy).

Pomocí modifikované metody byly změřeny anthokyany $v$ různých matricích (plody, sirupy, víno) s cílem vysvětlit možné ztráty aktivních látek při zpracování plodů a/nebo uchovávání produktů. Byly analyzovány vzorky výrobků dostupných v obchodní síti a doporučovaných obvykle jako cenný zdroj antioxidantů - $v$ některých byl nalezen jen malý obsah anthokyanů. $V$ modelovém uspořádání byly odděleně extrahovány anthokyany ze slupek a dužniny plodů Sambucus nigra. Ve všech vzorcích z různých kultivarů byly anthokyany přítomny převážně ve slupkách (až $90 \%$ celkového obsahu). Tyto i další faktory je nutno brát v úvahu při vývoji vhodné technologie, která by mohla podstatně zlepšit kvalitu výrobků z plodů.

Keywords anthocyanins - skin and pulp of berries - differential spectrophotometry-wild berry products

Klúčové anthokyany-slupka a dužnina plodů-diferenční spektrofotometrie-produkty z lesních plodů

slová:

\section{INTRODUCTION}

Anthocyanins used as colour additives in food (in Europe classified as E 163) or as natural health products are usually obtained from fruits (usually berries) of suitable plants. To ensure desired effects such as mitigation of oxidative stress, the sources and extraction methods should be optimised to give a maximum yield of active substances. Even fruits rich in anthocyanins might render just remnants of the original value after processing and/or storage (syrup, jam, wine). Therefore, evaluation of the true content of anthocyanins in consumer products is of principal importance. 
Anthocyanins as easily accessible active substances of plant origin have attracted attention recently. They are considered to be good natural antioxidants providing also an array of other health-promoting benefits (Wallace et al., 2014). Anthocyanins belong to the group of phenolic compounds responsible for red and blue colours of plant organs such as fruits, flowers and leaves. They are present in a wide range of fruits, vegetables and beverages, and as such are normal dietary components. Next to wine, also fruits of elderberry species and their cultivars, blackcurrant, blueberries, chokeberries and so on and products made from these natural sources are the most frequently used food components or supplements and also drugs. They are nutritionally important also because of their proven antioxidant activity. Also, a number of other beneficial health impacts have been reported that might explain their centuries-long popularity in traditional medicine. They were used, for example, for the treatment of gastrointestinal tract disorders (Hidalgo, 2012), to increase diuresis and as a diaphoretic (Wichtl, 2009). In modern applications, their role as antioxidants is valued in the prevention and treatment of 'civilisation' cardiovascular disease, diabetes and neurodegeneration. Anthocyanins have the antimicrobial activity, anticarcinogenic, vasoprotective and anti-inflammatory properties (Pojer et al., 2013). They are also reported to enhance vision, to improve memory and to have antiobesity effects $(\mathrm{He}, 2010)$. Anthocyanins are helpful in the prevention and control of various diseases by counteracting the imbalance of oxidative and antioxidative factors in the living systems. Anthocyanin rich fraction of blackcurrant fruit skin inhibits the proliferation of HepG(2) human liver cancer cells. Blackcurrant products could be used in the prevention and treatment of human hepatocellular carcinoma (Bishayee et al., 2010). Prevention and treatment of vascular problems belong to the most valued impacts of anthocyanins (Wallace, 2011). Also, the often mentioned 'French paradox', a relatively low incidence of coronary heart disease (CHD) in spite of a diet rich in saturated fats, is often explained by the counteraction of high anthocyanins consumption in red wine (Renaud, 1992).

It is clear that the information on the real amount of these multilaterally useful substances in the consumed berries and berry products is of fundamental importance. Considering the high diversity of anthocyanin molecules themselves and of matrices they are built in, it seems to be a rather difficult task to find a general-purpose anthocyanin content evaluation. Fortunately, the spectrophotometric manifestation of these highly conjugated systems shows many similarities so that reasonable unification of methods and data is possible.

The group of anthocyanins is wide, over 700 structurally distinct anthocyanin molecules have been identified. Anyway, all of the naturally occurring anthocyanins are based on the same skeleton of 2-phenylchromenylium (referred also as flavylium ion or 2-phenyl-1-benzopyrylium...Andersen et al.. 2014).

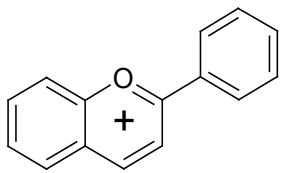

Substitution with $\mathrm{OH}$ or $\mathrm{OMe}$ groups at various positions renders a choice of anthocyanidins, yet just six of them are really common in plants: pelargonidin $(\mathrm{Pg})$, cyanidin (Cy), delphinidin ( $\mathrm{Dp})$, peonidin $(\mathrm{Pn})$, petunidin $(\mathrm{Pt})$ and malvidin (Mv). Glycosylation of these aglycons then finished the evolution of the wide variety of anthocyanins. In addition, the natural biosynthetic pattern may nowadays be transformed by genetic engineering aiming at the change of the pigmentation of plant parts, flowers or fruits in a desired way. In spite of the above-described plentitude of anthocyanin structures, most of them show the spectrophotometric features of rather similar chromophores.

Two most frequently used methods for anthocyanin analysis in real samples of fruits, berry products, wines and so on are: a rather simple spectrophotometric method and the more demanding HPLC measurement with UV (DAD) or MS detection. In both types of methods, the way to correct results includes well-defined and stable samples and the right choice and accessibility of standards and/or calculation procedures (Veberic et al., 2009). Results obtained by different methods are not always identical (Lee, 2007).

This study deals with the procedure most common in practice, the $\mathrm{pH}$ differential spectrophotometry recommended by the AOAC International, that is, the standards developing organisation formerly known as the Association of Official Analytical Chemists (AOAC, 2005). It is based on the welldefined and rather specific ability of anthocyanins to occur in a coloured (usually red) form in very acidic media ( $\mathrm{pH} 1-2)$ and lose the colour with increasing $\mathrm{pH}$, so that at the $\mathrm{pH}$ over 4.5, the colourless form prevails in most cases. The complicated pattern of acido-basic equilibriums includes, among others, the flavylium cation, a hemiketal form and both tautomers of chalcones (Quina, 2009). For simplicity, only two of these structures are usually mentioned (Fig. 1).

The difference of absorbances between two forms shown in Fig. 1, measured at the $\lambda_{\text {max. }}$ of the colour form, can be used as a selective measure of anthocyanins present in a sample, enabling to distinguish them from other pigments.

The term 'differential' is, however, slightly misleading. In the AOAC method, the difference, meaning the subtraction of the spectrophotometric data of the two forms of anthocyanins is applied, by no means any infinitesimal, differential changes. According to the original method, a known extinction coefficient $\varepsilon$ (molar absorptivity) of the prevailing anthocyanin should be used for the quantification. In practice, the content of anthocyanins in berries is often expressed as an equivalent of the most frequently occurring compound, cyanidin-3glucoside (C3G). It means that the $\varepsilon$ of C3G is used for most calculations, no matter which anthocyanins are really present. The total anthocyanin content is then usually given as $\mathrm{mg}$ 
<smiles></smiles>

$\mathrm{pH}$ 1-2 colour oxonium form<smiles>[R2]c1cc(C2(O)Oc3cc(O)cc(O)c3C=C2O)cc([R1])c1O</smiles>

$\mathrm{pH}>4.5$ colourless hemiketal form

Figure 1.pH-dependent structures of anthocyanins

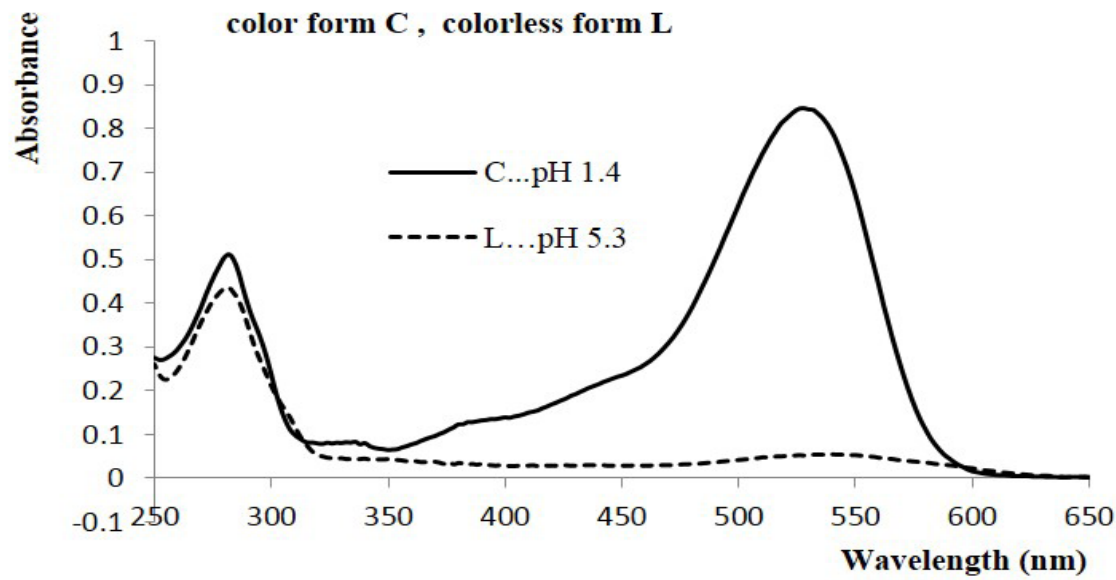

Figure 2. UV-VIS spectra of the reference standard cyanidin-3-glucoside

C3G: cyanidin-3-glucoside

CGE/100 $\mathrm{g} \mathrm{FW}$, that is, as an equivalent of C3G (mg) per $100 \mathrm{~g}$ (fresh weight) of the tested material. In Fig. 2, UV-VIS spectra of the colour form $\mathrm{C}(\mathrm{pH} 1.4)$ and colourless form $\mathrm{L}(\mathrm{pH}$ 5.3) of the reference standard C3G are compared.

The AOAC protocol provides better reproducibility than other methods used for the quality control of anthocyanincontaining products (Brooks, 2013). Anyway, it is somewhat limited by the necessity to calculate the anthocyanin content at the basis of properly chosen extinction coefficients, using suitable data found in the literature for measurements in similar media. This approach may give inaccurate results if anthocyanins present in the sample are not precisely defined and the extinction coefficients given in the literature were measured in dissimilar solvents. Better way is to use suitable reference standards; however, standards are usually expensive, not easily accessible and not always of the perfect quality. Results are then not fully comparable between laboratories (Lee, 2005).

The HPLC-UV/VIS measurements may be even less reliable. Probable reasons of irreproducible results may be hidden in varying $\mathrm{pH}$ values making the color or colorless forms poorly defined, in the instability of anthocyanins during extraction procedures or prolonged runs of HPLC measurements, in the variability due to complexation with copigments and so on. In this study, several refinements of the AOAC method have been used to increase its versatility and usefulness for a wide range of anthocyanin-containing fruits and products and to make the procedure more simple, reliable and environmentfriendly.

The principal refinement is that not only the reading of absorbances at a single wavelength $\left(\lambda_{\max }\right)$ is taken into calculations. In the modified method, the whole area under the differential spectrophotometric curve is evaluated, covering all chromophores with chemical and spectral features typical for anthocyanins (Polaskova et al., 2013).

As seen in Fig. 2, even in the simplest case of C3G, the spectral curve is rather broad and non-symmetrical. The asymmetry is ascribed to the variability of anthocyanins and their glycosides, to possible copigmentation and aggregation. The evaluation at one wavelength only might be inaccurate.

Modern instruments and computers make it easy not only to subtract the absorbance of the colourless form from that of the coloured form (i.e. to calculate the difference) at many wavelengths throughout the spectral curve (and thus to make the 'differential' curve) but also to integrate the area in a chosen wavelength range. In Fig. 3, showing the $\mathrm{pH}$-differential spectral curve of C3G, absorbances of the colourless form $L$ were subtracted from those of the colour form $C$. The area under the differential curve was evaluated. As stated above, in actual applications of the AOAC or other analytical methods, usually only one reference standard is used to evaluate the measurements. It then makes it easy to 


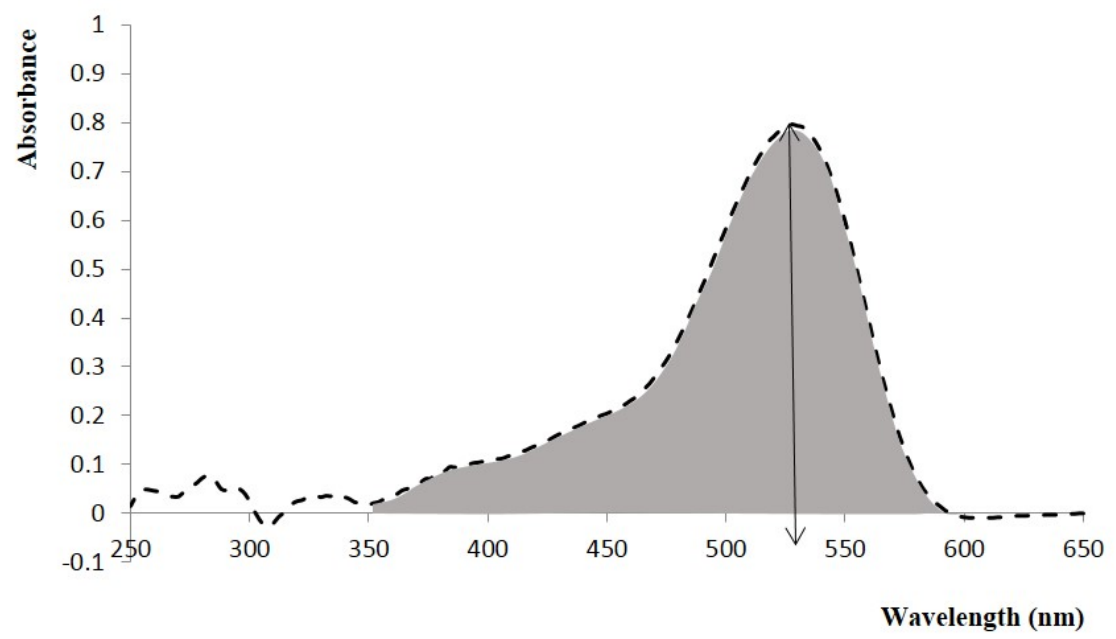

Figure 3. Area under the $\mathrm{pH}$-differential spectral curve of cyaniding-3-glucoside C3G: cyanidin-3-glucoside

unify and generalise the acquired data of various anthocyanin pigments in miscellaneous matrices using the equivalent unit of C3G, which is considered to be a typical and very often occurring representative of anthocyanins.

Also, in the modified method used in this study, the amount of anthocyanins is calculated and given in common units of $\mathrm{mg} \mathrm{CGE} / 100 \mathrm{~g} \mathrm{FW}$. The area under the differential curve (dAUC) of standard solutions of C3G is determined under the presumed experimental conditions and used for calibration instead of the $\varepsilon$ (molar absorptivity) of C3G.

A similar approach is sometimes used and validated for the determination of active substances in medical preparations (Chalikwar et al., 2012).

\section{MATERIAL AND METHODS}

\section{Plant material for tests}

Fruits of Sambucus nigra L. cultivars were harvested at optimum maturity at the grounds of the Research and Breeding Institute of Pomology, Holovousy. Other fruits to be analysed were collected in forests and gardens of East Bohemia. All fruits were immediately frozen and kept at $-20^{\circ} \mathrm{C}$ until the analyses were carried out.

To approximate food sources of anthocyanins, two commercial kinds of fruit syrup (both declared to contain 'wild berries') and three commercial samples of wine or fortified wine were tested - two sorts of port wine (Porto Cruz, Fine Ruby Port Croft) and a common red wine 'Modrý Portugal', Ravis, Moravia.

\section{Reference samples and chemicals}

The reference substance kuromanin chloride (cyanidin-3glucoside) was purchased from Polyphenols Laboratories AS (Norway). Citric acid, hydrochloric acid, sodium acetate, ethanol and so on, all of analytical grade, were supplied by Penta Chrudim (Czech Republic).

\section{Instrumentation}

HALO DB-20 Spectrophotometer (Dynamica GmbH., Austria), centrifuge type Z 326 K ( HERMLE, Germany), pH-meter Multi 340i (WTW, Germany), ultrasound water bath Bendelin (Sonorex, Germany).

\section{Procedure}

Fruit samples as well as fruit products $(5 \mathrm{~g})$ were mechanically homogenised in the presence of $0.5 \mathrm{ml} 1 \mathrm{M}$ citric acid. The homogeneous sample was mixed with aqueous $48 \%(\mathrm{v} / \mathrm{v})$ $\mathrm{EtOH}$, sonicated $(10 \mathrm{~min})$ and centrifuged $\left(5000 \mathrm{rpm}, 15^{\circ} \mathrm{C}\right.$, $15 \mathrm{~min}$ ). The supernatant was decanted and the procedure was once more repeated with the precipitated pellet. Supernatants from both extractions were collected into one vial. From $5 \mathrm{~g}$ of a sample, the total amount of $75 \mathrm{ml}$ of the final solution was prepared containing approximately $48 \%$ EtOH.

For final dilution, buffers were prepared according to AOAC method. $0.1 \mathrm{M} \mathrm{HCl}$ with $0.025 \mathrm{M} \mathrm{KCl}$ (buffer ' $C^{\prime}$ ) was used to provide for the coloured form of anthocyanins and 0.4 $\mathrm{M} \mathrm{Na}$ acetate adjusted to $\mathrm{pH} 4.5$ (buffer ' $\mathrm{L}^{\prime}$ ) for the colourless form. Unlike in the AOAC method, both buffers were subsequently treated to contain $48 \%(\mathrm{v} / \mathrm{v})$ of $\mathrm{EtOH}$. The $\mathrm{pH}$ of ethanolcontaining buffers was checked: the measured values of 1.4 for the buffer $C$ and 5.4 for the buffer $L$ differed from the nominal values of buffers without ethanol but still secured well-distinguishable forms of anthocyanins.

Extracts of berries or other fruit products were diluted with buffers to give the absorbance of the coloured form within the linear range of the standard calibration plot (Fig. 4). 


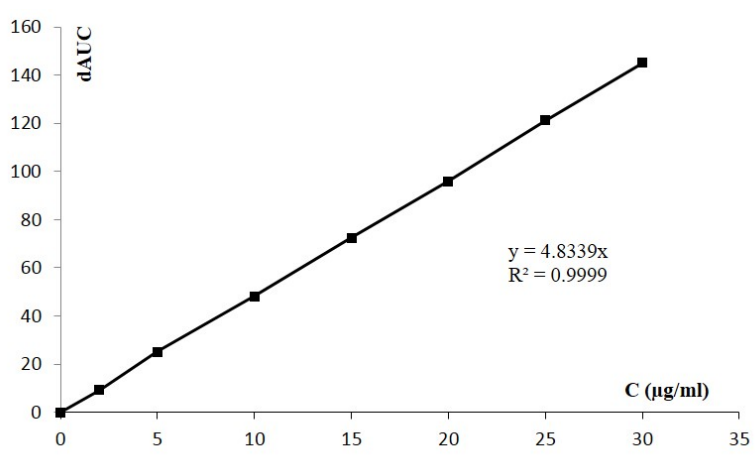

Figure 4. Calibration plot of the area under the differential spectrophotometric curve

The spectrophotometer was used in the wavelength scan mode to obtain spectrophotometric curves in the range from 250 to $700 \mathrm{~nm}$ (Fig. 2).

Using the UV Detective Plus software supplied with the spectrophotometer as a run controller, the 'differential spectrophotometric curve' defined in the AOAC protocol was acquired by subtraction of absorbances of the colourless form from the coloured one (Fig. 3).

Integration of an area under the 'differential' curve, demanded in the modified method of this study, proceeded also automatically. Reference area under the differential curve (obtained with calibration samples of C3G) was used for the assay of overall anthocyanin content in fruits and fruit products. In practice, using a calibration plot or a simple calibration equation, the overall content of anthocyanins in a sample was quantified as an equivalent of C3G, in common units of $\mathrm{mg}$ CGE/100 $\mathrm{g}$ FW.

\section{RESULTS AND DISCUSSION}

\section{Verification of the method - calibration curves}

A series of calibration solutions of the reference standard (C3G) were prepared using buffers according to the procedure. Concentrations were chosen to cover the full range of anticipated absorbances (ABS of the coloured form from 0.1 to 1.6). pH of all samples was checked. Pairs of equally diluted samples (coloured - $C$ and colourless - $\mathrm{L}$ ) were measured.

The linearity of the calibration curve is documented in Fig. 4 showing the area under the differential spectrophotometric curve dAUC (380-600 nm) vs. C3G concentration. For seven levels calibration, the coefficient of determination was 0.9999 . In Table 1, for this calibration curve, the values of absorbances and the corresponding areas under the differential curves (dAUC) are given for all concentration levels. It has been thus proven that the measurements of the areas under the differential curves can be applied in the range of linearity, that is, for absorbances from 0.1 to 1.6.

Finally, the relative contribution of anthocyanin concentration of $1 \mathrm{mg} / \mathrm{ml}$ (in the measured solution) to the area under the curve (dAUC) was calculated to facilitate future evaluations of practical samples. The obtained specific dAUC values usually measured in units $\left(\mathrm{nm} \mathrm{ml} \mathrm{mg}^{-1} \mathrm{~cm}^{-1}\right)$ for measurements performed in a $1-\mathrm{cm}$ pathlength cuvette - are shown in Table 1.

For this pilot type of study, only the basic statistical verification was performed, not the full validation process. Methods using areas under the dAUC were validated and found good for routine spectrophotometric analyses of drugs (Chalikwar et al., 2012). In our case, in the given calibration range, the average relative standard deviation (RSD) of $2.2 \%$ was achieved.

To confirm the precision of the method for real samples, three independent measurements were performed with three individually prepared samples of the fruits of Sambucus nigra. For readings in the middle part of the calibration curve, the RSD of $2.52 \%$ was confirmed.

The usefulness and eventual advantages of the refined AOAC method were documented by practical measurements.

\section{Application of the method - anthocyanins in various fruits}

AOAC official method - $\mathrm{pH}$ differential spectrophotometric measurements of anthocyanins was applied to compare anthocyanins present in fruits (berries) and in some berry products. Differential spectra of fruits of three common anthocyanin-rich species are shown in Fig. 5. In these cases, $1 \mathrm{ml}$ of measured samples contained anthocyanins extracted from $1 \mathrm{mg}$ of fruits.

As seen in Fig. 5, different kinds of berries give curves with non-identical shapes and different maximum wavelengths. Calculations based on a single absorption coefficient of the C3G according to the original AOAC method would not be quite correct from the physical point of view. The accuracy of calculations with the $\varepsilon$ of C3G (molar absorptivity of the standard) is somewhat dubious when the measured sample shows a different maximum wavelength and/or the spectrum is broader, indicating that more than one chromophore may be present.

The modified method using the whole spectrophotometric curve of C3G to gain a reference value might also not be strictly physically correct but, at least, it takes into better consideration all chromophores showing the features of anthocyanins that are present in the sample under actual conditions.

There are more reasons making the real samples inhomogeneous, even in the case of only one chromophore. Under equal conditions, the maximum wavelength of a defined chromophore might be shifted due to the intermolecular interactions (Lee, 2005).

\section{Alcohol-containing samples}

Another uncertainty of anthocyanin determination, both spectrophotometric and HPLC - UV/VIS, lies in the varying 
Table 1. Calibration parameters of standard cyanidin-3-glucoside solutions

\begin{tabular}{|c|c|c|c|c|}
\hline \multirow{2}{*}{$\begin{array}{c}\text { Conc. } \\
\left(\mu \mathrm{g} \mathrm{ml}^{-1}\right)\end{array}$} & \multirow{2}{*}{$\begin{array}{l}\lambda_{\max } \\
(\mathrm{nm})\end{array}$} & \multirow{2}{*}{$\begin{array}{l}\max \\
\text { ABS } \\
\end{array}$} & \multicolumn{2}{|c|}{$\begin{array}{c}\text { Area under the } \\
\text { dAUC in the range } 380-600 \mathrm{~nm}\end{array}$} \\
\hline & & & dAUC (nm) & specific dAUC $\left(\mathrm{nm} \mathrm{ml} \mathrm{gg}^{-1} \mathrm{~cm}^{-1}\right)$ \\
\hline 0 & & 0.0 & 0 & \\
\hline 2 & 530.5 & 0.103 & 9.19 & 4.6 \\
\hline 5 & 526 & 0.279 & 25.07 & 5.01 \\
\hline 10 & 526.5 & 0.539 & 48.11 & 4.81 \\
\hline 15 & 529 & 0.798 & 72.51 & 4.83 \\
\hline 20 & 525.5 & 1.064 & 95.94 & 4.8 \\
\hline 25 & 526 & 1.343 & 121.24 & 4.85 \\
\hline 30 & 527.5 & 1.635 & 145.14 & 4.84 \\
\hline mean & & & & 4.82 \\
\hline RSD & & & & $2.2 \%$ \\
\hline
\end{tabular}

C3G: cyanidin-3-glucoside; dAUC: differential curve, RSD: relative standard deviation

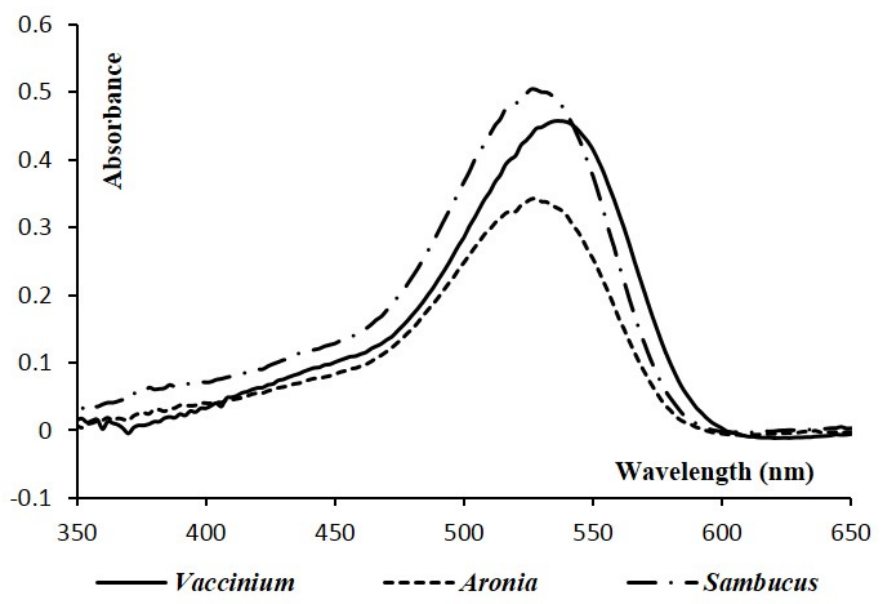

Figure 5. Differential spectrophotometric curves of anthocyanin- rich berries

composition of the solution. The molar absorptivity is usually tabulated for solutions containing various amounts of organic solvents. Methanol is often used for extractions. Some samples, for example, wines, already contain ethanol for these mixed solvents, no exact literature data exist.

In the AOAC method of differential spectrophotometry, the exact $\mathrm{pH}$ of buffer solutions is essential for ensuring really coloured and really colourless forms of anthocyanins. With the changing content of alcohols, $\mathrm{pH}$ of samples changes. It is then wrong to suppose that the nominal $\mathrm{pH}$ of the originally prepared buffer is true also in ethanol mixtures - and the spectral behaviour of samples would change accordingly.

Fig. 6 documents spectral changes of coloured and colourless forms of C3G due to different ethanol addition to buffers prepared originally (AOAC procedure) as water solutions.

This complication might be serious in case of measuring the content of anthocyanins in wines or other ethanol-containing beverages. To cope with this, in the proposed method, both buffers $\mathrm{C}$ (strongly acidic) and $\mathrm{L}$ (pH over 4.5) are immediately mixed with the same amount of $96 \%$ ethanol (giving the final content of about $48 \%$ of ethanol). The $\mathrm{pH}$ is checked to secure the prescribed conditions for the coloured and the colourless form of anthocyanins. In this arrangement, the definability of all samples is better - additional smaller variation of ethanol content due to its presence in the original samples would not influence the character of the buffers substantially. Of course, all calibration measurements should be made in the same ethanol-containing buffers.

Even the extraction procedures take advantage of alcoholcontaining media (about $48 \%$ ethanol) - see the preparation of extracts.

Another phenomenon causing less reliable results is the high probability of copigmentation due to complexes of anthocyanins with organic acids and other substances 


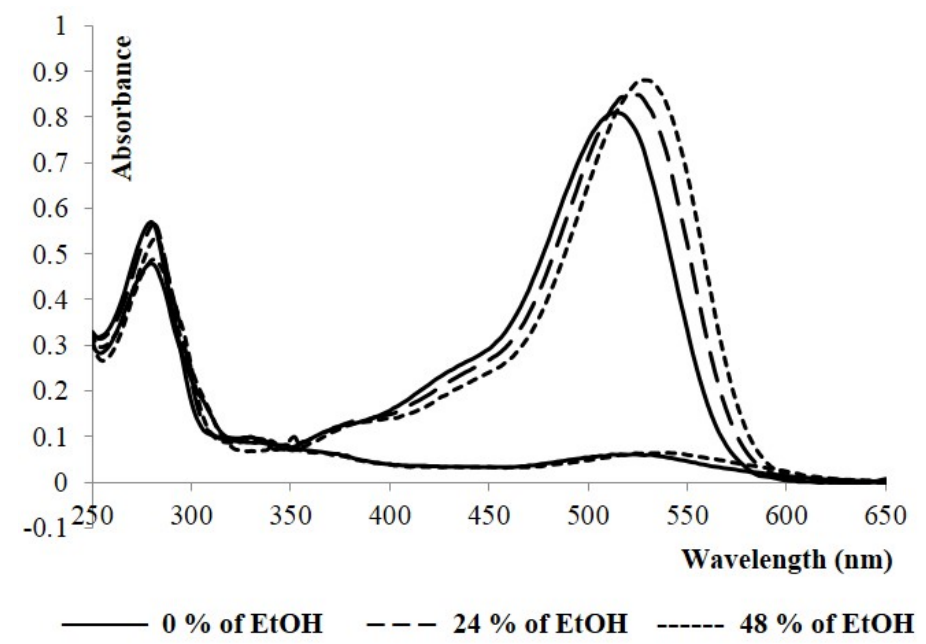

Figure 6. Spectral changes due to the differential ethanol content

including metals, other polyphenols and so on. These reagents are present in buffers for the spectroscopy, in mobile phases for HPLC and in most real samples of anthocyanincontaining fruits and products. The otherwise valued copigmentation of anthocyanins (enabling to preserve the coloured forms of parts of plants even at higher physiological $\mathrm{pH}$ ) may cause complications when colourless forms are needed for measurements. Many attempts were made to make the routine handling and analysis of samples more simple, fast, gentle, accurate and reproducible (Yousef et al., 2013). The presence of a defined amount of citric acid in the course of extraction would outweigh the unpredictable copigmentation phenomena.

An additional asset of increased ethanol and citric acid contents in samples is the increased stability. It is highly recommendable to stabilise samples already at the very beginning of any treatment, usually before melting of frozen samples. As soon as the temperature increases, enzymes start their action. In the modified procedure proposed in this study, samples are treated with citric acid immediately, in the course of melting, and the sonication (as an important part of anthocyanin extraction) proceeds in the presence of ethanol. Both concentrated extracts and samples diluted for the spectrophotometry showed very good stability. The loss of anthocyanins in real samples, observed 24 hours after their extraction from fruits, did not exceed $9 \%$, so that the hardly achievable AOAC recommendation - to measure within an hour - is not necessary to obey.

In addition, the proposed procedure is environment-friendly. Some other methods that have proclaimed themselves as environment-friendly still use methanol and trifluoracetic acid (Grigoras et al., 2012). In the method, according to this study, ethanol, citric acid and sodium acetate are needed; just the hydrochloric acid used for the acid buffer might be dangerous, even if it is also a normal gastric fluid.

This approach seems to be very practical for the evaluation of wines. As an example, anthocyanin content in three sorts of commercially accessible wines (or fortified wines) was compared (Fig. 7).

As mentioned in the introduction, the so called French paradox of low incidence of cardiovascular diseases in people with a seemingly unhealthy diet is at least partially ascribed to drinking wine. Since the spectra of wines are very complex, dAUC facilitate the 'separation' of anthocyanins from other, albeit also potentially favourable components of wine. As an illustration of the advantages of the method, different wine types were compared: two sorts of port wine (fortified red wines) and a common red wine from Moravia. For measurements, the samples were diluted 20 times by the appropriate buffers to get the coloured and the colourless forms of anthocyanins. However, no really colourless solutions were obtained, namely, with port wines. Only the area of dAUC could give reasonable basis for evaluation since there were hardly any maxima of absorbances observable in some of the samples that would be necessary for calculations on the basis of extinction coefficients. The spectra of the coloured forms and the corresponding dAUC are shown in Figs. 7a and b. Content of anthocyanins in the wines was rather low: only 2 mg CGE/ $100 \mathrm{~g}$ of Porto Cruz, 13.5 mg CGE/ $100 \mathrm{~g}$ of Fine Ruby Porto Croft and $7 \mathrm{mg} \mathrm{CGE/} 100 \mathrm{~g}$ of Portugal. It is clear that these results can hardly explain the unquestionable quality of port wines, namely, the old ones. It is supposed that during ageing, anthocyanin monomers content decreases and other substances, perhaps also of polyphenol health-promoting type can be increasingly detected (Mateus et al., 2001).

\section{Anthocyanins in the skin and the pulp of Sambuci fructus}

The method of differential spectrophotometry was used to compare different cultivars of Sambucus nigra (European elderberry), which is a frequent practical task demanded by plant breeders nowadays (Braga et al., 2002). As one of the practical problems, the distribution of anthocyanins between 

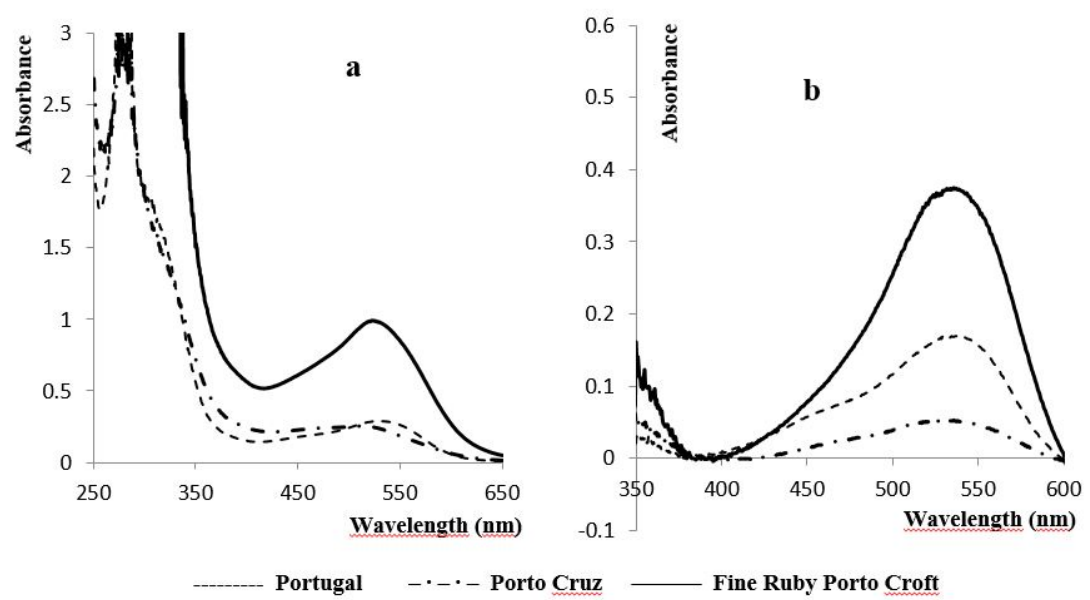

Figure 7. Spectra of colour forms (a) and differential spectrophotometric curves (b) of three kinds of wine

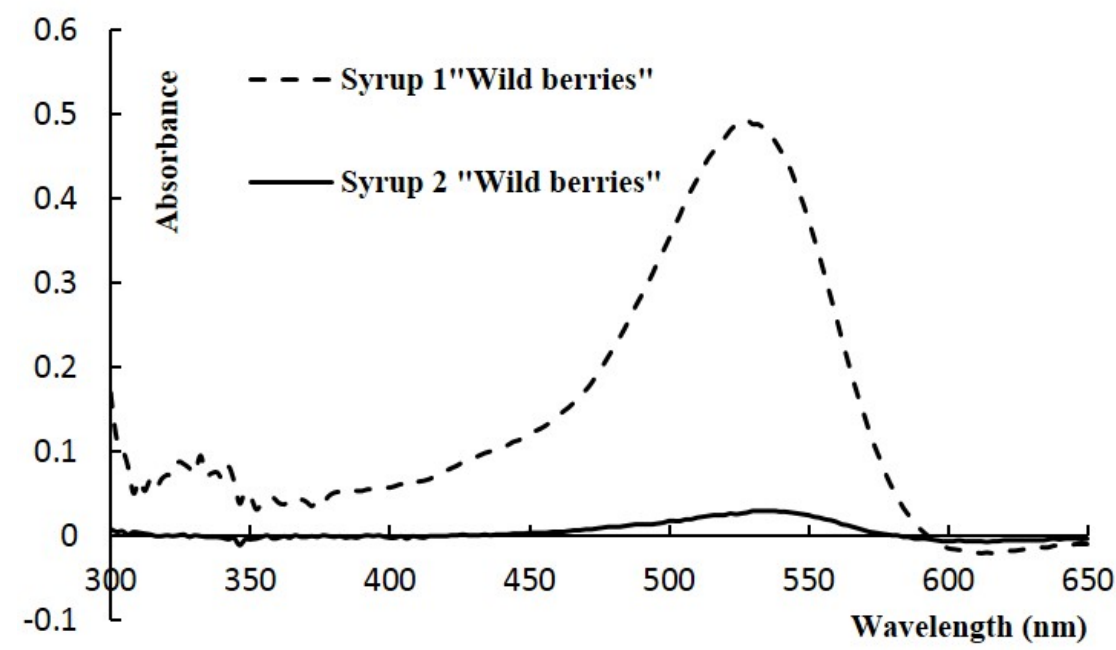

Figure 8. Commercial berry products

the exocarp (skin) and the mezocarp (pulp) of the fruits was studied, which may be important for theoretical (ripening. secondary metabolism) and practical (food industry) purposes. For calculations, calibration plot acquired for the reference standard C3G was used.

A choice of cultivars were tested for this ratio, with similar results: the prevailing portion of anthocyanins (upto

$90 \%$ ) was present in the skin of fruits, though the proportion of skin in the total weight was lower. It is necessary to consider this fact to avoid unwanted losses of active substances during processing. Distribution of anthocyanins between the skin and the pulp of elderberry fruits (Sambucus nigra - wild plants and various cultivars) is shown in Table 2.

\section{Anthocyanins in processed products}

Neglecting the above given distribution of pigments and some other factors determining the yield of anthocyanins may lead to very low content of the desirable components of berry products. Two commercial berry products of different producers, with generally the same declaration of 'wild berries' content were analysed (repeatedly), with the results - differential spectrophotometric curves - shown in Fig. 8. Thanks to the selectivity of the $\mathrm{pH}$-differential method, anthocyanins can be determined even in the presence of other pigments eventually contained in the sample.

In addition to the above documented uneven distribution of anthocyanins in fruits, also the post-harvest treatment of fruits and conditions during the processing of fruit products (freezing or drying, $\mathrm{pH}$, temperature) might play a role. In the dried fruits of Sambucus nigra, hardly any anthocyanins were found (Nehybova, 2014).

\section{CONCLUSIONS}

A modified spectrophotometric method was developed and verified for the determination of anthocyanins. The original differential spectrophotometry recommended by AOAC 
Table 2. Distribution of anthocyanins between the skin and the pulp of elderberry fruits

\begin{tabular}{|c|c|c|c|c|c|c|}
\hline \multirow{2}{*}{$\begin{array}{c}\text { Sambucus } \\
\text { nigra }\end{array}$} & \multirow{2}{*}{$\begin{array}{c}\text { Proportion } \\
\text { of skin mass }\end{array}$} & \multicolumn{2}{|c|}{ Cyanidin-3-equivalent CGE $(\mathrm{mg} / 100 \mathrm{~g})$} & \multicolumn{2}{c|}{ Anthocyanin distribution } \\
\cline { 3 - 7 } & & Pulp & Skin & Total & Pulp & Skin \\
\hline Wild plants & $35 \%$ & 104 & 909 & 1013 & $10 \%$ & $90 \%$ \\
\hline SAMBU & $38 \%$ & 252 & 982 & 1234 & $20 \%$ & $80 \%$ \\
\hline SAMBO & $45 \%$ & 576 & 728 & 1304 & $44 \%$ & $56 \%$ \\
\hline SAMDAL & $38 \%$ & 483 & 1325 & 1808 & $27 \%$ & $73 \%$ \\
\hline SAMYL & $48 \%$ & 504 & 1218 & 1722 & $29 \%$ & $71 \%$ \\
\hline
\end{tabular}

International (i.e. the standards developing organisation formerly known as the Association of Official Analytical Chemists), is based on the reversible $\mathrm{pH}$-dependent transformation of the colour to the colourless form of anthocyanins. According to the original AOAC method, a known extinction coefficient $\varepsilon$ (molar absorptivity) of the prevailing anthocyanin should be used for the quantification. This quantity is, however, not always and not precisely accessible. In practice, the content of anthocyanins in berries is often expressed as an equivalent of the most frequently occurring compound, C3G, using its $\varepsilon$ in possibly similar media for calculations, which are based on a single-absorption measurement at the maximum wavelength.

The refined method presented in this study is more illustrative and versatile. Instead of the absorbance measured at the maximum wavelength, the whole area under the spectrophotometric curve (in the region of anthocyanins) is integrated via an automated programme provided by most spectrophotometers. The method thus better enables laboratories to quantify various complexes and aggregates of anthocyanins present in real samples and also to analyse the wide variety of anthocyanins contained in various fruits (berries) and berry products.

As the practical application of the method, a contribution to anthocyanin containing species breeding and fruits processing is presented. The ratio of anthocyanins in the skin and the pulp and the total content in fruits of various Sambucus nigra cultivars were evaluated, proving a highly prevailing amount of pigments in the skin. The importance of conscious processing was documented also by a comparison of two commercial products - wild berry syrups, with very different content of anthocyanins.

The refined differential spectrophotometric method provides also improvements in sample preparation steps, useful, namely, for wines and other alcohol-containing beverages. Three varieties of red wine were compared and the relatively low content of anthocyanins commented upon.

\section{References}

[1] Andersen QM, Jordheim M. Basic Anthocyanin Chemistry and Dietary Sources. In: Wallace TC, Giusti MM ed. Anthocyanins in Health and Disease. Boca Raton: CRC Press; 2013.

[2] Bishayee A, Haznagy-Radnai E, Mbiba T, et al. Anthocyanin-rich black currant extract suppresses the growth of human hepatocelular carcinoma cells. Nat. Prod. Commun. 2010;5:1613-1618.

[3] Braga FG, Carvalho LM., Carvalho MJ, Guedes-Pinto H, TorresPereira JM, Neto MF, Monteiro A. Variation of the anthocyanins content in Sambucus nigra L. population growing in Portugal. J. Herb. Spic. Med. Plants 2002;9:289-295.

[4] Brooks LM, Kuhlman BJ, McKesson DW, McCloskey L. Poor interoperability of the Adams-Habertson method for analysis of anthocyanins: Comparison with AOAC pH differential method. J. AOAC Int. 2013;96:86-90.

[5] Chalikwar, SS, Shirkhedar AA, Bagul MA, Jain PS, Surana SJ. Development and validation of zero and first-order derivative area under curve spectrophotometric methods for the determination of entcapone in bulk material and in tablets. Pharm.Methods 2012;3:14-17.
[6] Grigoras CG, Destandau E, Zubrycki S, Elfakir C. Sweet cherries anthocyanins: An environment friendly extraction and purification method. Sep. Purif. Technol. 2012;100:51-58

[7] He J, Giusti MM. Anthocyanins: Natural colorants with healthpromoting properties. Annu. Rev. Food Sci. Technol. 2010;1:163187.

[8] Hidalgo M, Oruna-Concha MJ, Kolida S. Metabolism of Anthocyanins by Human Gut Microflora and Their Influence on Gut Bacterial Growth. J. Agric. Food Chem. 2012;60:3882-3890.

[9] Lee J, Durst RW, Wrolstad RE. Total Monomeric Anthocyanin Pigment Content of Fruit Juices, Beverages, Natural Colorants, and Wines: AOAC Official Method 2005.02;2005

[10] Lee J. Determination of total monomeric anthocyanin pigment content of fruit juices, beverages, natural colorants and wines by the $\mathrm{pH}$ differential method: Collaborative study. J. AOAC Int. 2005;88:1269-1278.

[11] Lee J, Finn CE. Antocyanins and other polyphenolics in American elderberry (Sambucus canadensis) and European Elderberry (S. nigra) cultivars. J. Sci. Food Agric. 2007;87:2665-2675. 


\section{Factors affecting the actual yield of active substances from anthocyanin-rich berries}

[12] Mateus N, de Freitas V. Evolution and stability of anthocyaninderived pigments during port wine aging. J. Agric. Food Chem. 2001;49:5217-5222.

[13] Nehybova M. Antioxidant activity of fruits of various cultivars Sambucus nigra [thesis]. Hradec Kralove: Faculty of Pharmacy; 2014.

[14] Pojer E, Mattivi F, Johnson D, Stockley CS. The case for anthocyanin consumption to promote human health: A review. Compr. Rev. Food Sci. F. 2013;12:483-508.

[15] Polaskova A, Spilkova J, Matejicek A. (2013. September). Anthocyanins in berry. A novel versatile evaluation of $\mathrm{pH}$ defferential spectra. Poster presented at: the IWA ( $7^{\text {th }}$ International Workshop on Anthocyanins); September 2013; Porto, PT.

[16] Quina FH, Moreira PF, Vautier-Giongo C, et al. Photochemistry of anthocyanins and their biological role in plant tissues. Pure Appl. Chem. 2009;81:1687-1694.

[17] Renaud S, de Lorgeril M. Wine, alcohol, platelets, and the French paradox for coronary heart disease. Lancet 1992;339:1523-1526.
[18] Studena H. Quality of fruits of Sambucus nigra cultivars [thesis]. Hradec Kralove: Faculty of Pharmacy; 2014.

[19] Veberic R, Jakopic J, Stampar F, Schmitzer V. European elderberry (Sambucus nigra L.) rich in sugars, organic acids, anthocyanins and selected polyphenols. Food Chem. 2009;114:511-515.

[20] Wallace TC. Anthocyanins in cardiovascular disease. Adv. Nutr. 2011;2:1-7.

[21] Wallace TC, Giusti MM ed. Anthocyanins in Health and Disease. Boca Raton: CRC Press; 2013.

[22] Wichtl M. Teedrogen und Phytopharmaka. 5. Ed. Stuttgart: Wissenschaftliche Verlagsgesellschaft. 2009: 601-602.

[23] Yousef GG, Brown AF, Funakoshi Z, et al. Efficient quantification of the health-relevant anthocyanin and phenolic acid profiles in commercial cultivars and breeding selections of blueberries (Vaccinium spp.). J. Agric. Food Chem. 2013;61:4806-4815. 